\title{
Tchibamba, Stanley, and Conrad: postcolonial intertextuality in Central African fiction
}

Paul Lomami Tchibamba (1914-85) is often described as the Congo's first novelist. Previous research in French and English has depicted Tchibamba's work as a straightforward example of 'writing back' to the colonial canon. However, this article advances scholarship on Tchibamba's work by demonstrating that his later writing responds not only to Henry Morton Stanley's account of the imperial subjugation of the Congo, but to Joseph Conrad's questioning of colonialist narratives of 'progress'. Drawing on recent theoretical work that examines intertextuality in postcolonial fiction, this article demonstrates that while Tchibamba is highly critical of Stanley, he enters into dialogue with Conrad's exposure of colonial brutality. Bringing together comparative research insights from Congolese and European literatures, this article also employs literary translation. This is the first time that excerpts from two of Tchibamba's most important responses to colonial authors have been translated into English. Also for the first time, Tchibamba's novella Ngemena is shown to be a crucial postcolonial Congolese response to Heart of Darkness. Through close textual analysis of Tchibamba's use of irony and imagery, this article's key findings are that, while Tchibamba nuances Conrad's disparaging portrait of a chief, he develops the ironic mode of Conrad's An Outpost of Progress, and updates the journey upriver into the interior in Heart of Darkness. This article illustrates the complex and nuanced way in which Tchibamba interacts with his European intertexts, deploying close analyses of his responses to Conradian imagery. Keywords: African fiction, Congo, Joseph Conrad, intertextuality, Paul Lomami Tchibamba.

\section{Introduction}

Paul Lomami Tchibamba (1914-85) is often described as the Congo's first novelist (Kadima-Nzuji 8). Previous research in French and English has depicted Tchibamba's work as a straightforward example of 'writing back' to the colonial canon. However, this article shows that Tchibamba enters into a complex dialogue with two major colonial authors: Henry Morton Stanley and Joseph Conrad. It is surprising that scholarship about Tchibamba's work has been so scarce: the few English-language works on his novels include Pierre Halen, Kasongo Kapanga ("Legitimizing the invented Congolese space: The gaze from within in early Congolese fiction"; The Writing of the Nation: Expressing Identity through Congolese Literary Texts and Films), and Susanne Gehrmann. This article advances research on Tchibamba's work by devoting space to lesser-known - but highly important—novellas that respond to Stanley and Conrad: N'Gobila des Mswata et Mistantèle (N'Gobila of the Mswata and Mistantèle, 1972) and Ngemena (1981). Bringing together comparative research insights from Congolese literature and the European authors Tchibamba read, this article also employs literary translation. Sections from these two important novellas are translated into English for the first time here, as none of Tchibamba's books have been translated into English in their entirety. ${ }^{1}$ This article reveals for the first time that Ngemena is a highly significant postcolonial response to Heart of Darkness, offering a crucial Congolese perspective on the river-journey into the interior. Many earlier scholars who examine Tchibamba's references to European culture follow a simplistic model of counter-discourse, without acknowledging the complexity of his relationship to European authors. Gehrmann has written of "the textual confrontation with Joseph Conrad" in Tchibamba's novella N'Gobila (15), ignoring Conrad's exposure of the difficulties of the colonialist project and scarcely examining Tchibamba's engagement with Henry Morton Stanley's writings. Silvia Riva has conceded that Tchibamba's fantastical landscapes owe a debt to nineteenth-century aesthetic devices such as the diorama, but then incongruously argues that the fantasy realms of this era constitute "la cible principale des attaques de Tchibamba" (the main target of Tchibamba's attacks) (Riva 74).

Riva and Gehrmann's oppositional model of Tchibamba's writing is problematic: it glosses over the com-

Yvonne Reddick is a research fellow at the Institute for Black Atlantic Research, Faculty of Culture and the Creative Industries, University of Central Lancashire, Preston, United Kingdom. Her monograph is Ted Hughes: Environmentalist and Ecopoet.

Email:yreddick@uclan.ac.uk

(D) https://orcid.org/0000-0002-7869-7560

DOI: dx.doi.org/10.17159/2309-9070/tvl.v.56i2.5639 
plexities of his intertextual responses to earlier authors, brands colonial-era literature as a uniform entity, and ignores the forms of (foreign and internal) oppression that replaced colonialism. In fact, in a preface to Ngemena, Tchibamba wrote that his novella was not only a trenchant critique of colonialism, but offered a cautionary moral for Western "néo-colonialisme" (Ngemena 8) that persisted after independence and benefited the Congolese ruling classes. If Tchibamba is highly critical of Stanley, he enters into an intricate ideological and literary dialogue with Conrad's exposure of the Congo Free State's brutality. Moreover, scholars such as Kadima-Nzuji have long known that Tchibamba particularly appreciated certain European authors, especially Jules Verne (226). Conrad is important for Congolese writers: according to Kapanga, "Heart of Darkness holds a special place in Congolese history and literature" (Writing of the Nation 137). He has shown how "Congolese writers such as Mudimbe and Ngandu Mkashama [...] have confronted the claim of darkness in their writings", although their responses to Conrad are oblique. Understandably, Kapanga is troubled by Conrad's depiction of the Congo as "wilderness where rudimental souls are trapped" (147). Nevertheless, he examines how Conrad's An Outpost of Progress "highlights the contradictions between the colonial ideology's stated ideals and the reality on the ground where acts of betrayal and treacherous behaviour evidenced gross incompetence" (148). Kapanga's account does not deliver any close analyses of how Congolese authors have responded to Conrad's imagery in Heart of Darkness or his ironic tone in An Outpost of Progress - nor is Stanley's narrative mentioned. There is a brief glance at similarities between the way trade and power are depicted in Heart of Darkness and Ngando (143), but these similarities are not discussed in detail. Congolese authors are still characterised as "writing back" and "counter[ing] the discourse that erased their presence" (150): neither Tchibamba nor Conrad conforms to such a simplistic model. This article analyses postcolonial intertextuality in two of Tchibamba's novellas, N'Gobila des Mswata et Mistantèle and Ngemena.

The two works examined in this article are historical fiction: N'Gobila is set in the early days of European subjugation of the Congo for King Leopold II, while Ngemena is set during the colonial Belgian Congo era. Both were published during Mobutu's drive for authenticité, which aimed at ridding the Congo of colonial influence and creating a new cultural consciousness for the country. In keeping with Mobutu's attempts to undo imperial cultural influence, Tchibamba does offer a cultural corrective to Henry Morton Stanley's account of his establishment of a station at Kimpoko in N'Gobila. Yet Riva and Gehrmann oversimplify Tchibamba's work when they characterise it as univocal "textual confrontation" or blunt "attaque" on European literature.

Tchibamba's career as a novelist began with the publication of his award-winning novella Ngando in 1948, which sets a traditional tale of the spirit-world in the time of early European colonialism. He had preceded it with an article on the status of the "évolués" (the educated Congolese middle class), in the magazine La Voix du Congolais, in 1945-and received a brutal flogging from the colonial administration (Tchibamba and Lomomba 40). He followed these works with the magical realist short story "La Récompense de la cruauté" (The Reward for Cruelty) and the historical novella N'Gobila, both written in 1971 and published by Valentin Mudimbe's imprint Le Mont Noir the following year. 1974 saw the publication of his realist novella Faire médicament (Making Medicine), set in the Oubangui region, and his magical realist novella Légende de Londema (The Legend of Londema). Ngemena, an historical tale of a river-journey that exposes racial and class-related fault lines, appeared in 1981. His last novel, Ah! Mbongo (Oh! Money) was begun after 1948, went through many drafts, and was finished in 1978. The novel was posthumously published, with Alain Mabanckou's editorial help, in 2007. Several other works appeared posthumously in La Saga des Bakoyo Ngombé et autres inédits (The Saga of the Bakoyo Ngombé and Other Unpublished Works) in 2014. Silvia Riva identifies Ngando, "La Récompense de la cruauté", elements of N'Gobila, and Légende de Londema as Tchibamba's "cycle du merveilleux" (fantastical cycle) (Riva 75), employing elements of magical realism, whereas novels such as Ah! Mbongo are more "picaresque[s]" (80).

Tchibamba's writing certainly criticises colonial brutality, but Riva and Gehrmann's work proposes an excessively oppositional model of colonial and postcolonial literature. Over a decade before they published their work about Tchibamba, Elleke Boehmer complicated the 'warring dichotomy' of postcolonial texts versus their canonical European predecessors:

$[T]$ he postcolonial tends automatically to be thought of as multi-vocal, 'mongrelized,' and disruptive, even though this is not always the case. Similarly [...] the colonial need not always signify texts rigidly associated with the colonial power. Colonial, or even colonialist writing was never as invasively confident or as pompously dismissive of indigenous cultures as its oppositional pairing with postcolonial writing might suggest. (Boehmer 4)

Further important work on the significance of canonical European authors for African literature has been con- 
ducted by Byron Caminero-Santangelo, who notes that "In an effort to place the 'classics' in a colonial tradition, those ascribing to the 'writing back' model reduce their significance to a collusion with colonial discourse" (15). Conrad's work is an obvious choice of intertext for authors writing from, and about, Central Africa. While Achebe engaged antagonistically with Conrad in his famous essay "An Image of Africa", later postcolonial authors have responded to and updated Conrad in a more dialogic way. Major postcolonial authors such as V. S. Naipaul and Ngũgĩ wa Thiong'o align their work with Conrad's (Naipaul; Duerden and Pieterse). Caminero-Santangelo has researched intertextual references to Conrad in African authors from Chinua Achebe to Ama Ata Aidoo, while Rebecca Fasselt shows how Ngũgĩ follows Conrad by destabilising race, gender, and class boundaries. Caminero-Santangelo writes that "a good deal of African literature is focused on some form of colonialism and the need for decolonization", yet he stresses that "colonialism is not a monolithic entity; its form and ideology change" (17). In addition, it is important to acknowledge that after African countries gained independence from European colonialism, new forms of oppression did sometimes replace colonialism. Ania Loomba has cautioned that "'Colonialism' is not just something that happens from outside a country or a people, not just something that operates with the collusion of forces inside, but a version of it can be duplicated from within" (32). Tchibamba is highly aware of both collusion and internal oppression.

\section{Mobutu's 'recourse to authenticity'}

In 1965, the Congolese chief of the armed forces, Joseph Désiré Mobutu, seized power in the Congo. He would rule the country for thirty-two years, changing its name to Zaïre from 1971 to 1997. Mobutu's coup had financial and military backing from Belgium and America (Badru 153) - one example of a policy that shows that Congolese independence was not a clean break with western powers, and the origin of Tchibamba's statement that the government benefited from "néo-colonialisme". From 1966 onwards, Mobutu began to develop ideas that ultimately led to a policy called the recours à l'authenticité. This doctrine was first laid down in 1967, in the Manifesto of N'Sele, which would become official national policy (Lagae and De Raedt 179). Yet it is important to emphasise that Mobutu decided to employ the term recours (appeal to, recourse to) as opposed to the originally proposed retour (return) (Adelman 138). The slogan "Tribu oui, tribalisme non" (yes to tribes, no to tribalism) aimed to avoid the politicisation of Congolese ethnic groups that had formerly caused the nation to fragment, while acknowledging that tribal affiliation could not be done away with completely (Wright 86). Affiliation to one's ethnic group was not conducive to national unity in a country as vast as the Congo, which has over 360 different social and ethnic groups (Fraiture 8). The very concept of different ethnic groups was partly fabricated by colonial ethnographers to facilitate domination (van Reybrouck 1ll-2); such policies had disastrous results in neighbouring Rwanda. Mobutu's state commissioner for information aimed to replace tribal affiliation with allegiance to a national "tribe" (351). Cultural reforms to implement this ideology included "changing the words of traditional songs and chants so as to praise the President and the national party" (Adelman 135). In a 1974 speech addressed to the United Nations, Mobutu explained the authenticity policy as consisting of:

Une prise de conscience du peuple zaïrois de recourir à ses sources propres, de rechercher les valeurs de ses ancêtres, afin d'en apprécier celles qui contribuent à son développement harmonieux et naturel. C'est le refus du people zaïrois d'épouser aveuglement les idéologies importées.

The people of Zaïre's realisation (of the need) to refer to its own roots, to search for the values of its ancestors in order to appreciate those that contribute to its harmonious and natural development. It is the Zaïrian people's refusal to embrace imported ideologies blindly. (qtd in Lagae and De Raedt 118)

In terms of its popular reception, Kapanga has said that "At first, the policy was seen very positively although it had its doubters" (Kapanga and Reddick). In addition to reforms such as a new national dress, the removal of colonial monuments, and the Africanisation of names (Adelman 135), "Culture was seen as a key instrument to 'decolonize' the nation" (Lagae and De Raedt 179). Of course, this came with contradictions: the new national dress, the abacost, was modelled on Maoist garb; musician Camille Feruzi played the accordion (van Reybrouck 355) rather than the traditional lokole. Exhibitions, artistic commissions, and studies on Congolese art became important means for fomenting interest in a national culture. However, "the strong hold of the president on all forms of artistic expression was peculiar, leaving little manoeuvring space for other cultural agents or artists wanting to work outside of the official guidelines" (Lagae and De Raedt 179). Some of the dictator's attempts to don a chief's mantle were met with skepticism: Kapanga notes that "Mobutu did wrap himself in the role of the 
traditional chief (by his behavior and rationale), but people could not give it to him because he did not have a royal blood line" (Kapanga and Reddick). Outright resistance to the regime was brutally crushed: after six months in power, Mobutu publicly hanged four leaders of a supposed plot against him. ${ }^{2}$ Public executions had not happened in the Congo since colonial times (van Reybrouck 336, 339), although the earlier loss of thousands of lives due to rebellions and massacres meant that the public reaction to the hanging was somewhat muted.

Consequently, there was little room to manoeuvre outside official guidelines. Between 1965 and 1975, Tchibamba worked at several minor official posts under Mobutu's rule. According to his daughter, Eliane Tchibamba who wrote the preface to the novel Ah, Mbongo:

Il est désillusionné par la création de partis uniques dans les anciennes colonies, qui font preuve des mêmes tendances répressives et des mêmes intolérances que l'administration coloniale de naguère. Les nouvelles hiérarchies ne supportant aucune critique, on le met "au placard" à l'ONRD (Office national de recherches pour le développement).

He [was] disillusioned by the creation of single parties in former colonies, which came to demonstrate the same repressive tendencies and intolerance as the former colonial administration. [Since] the new hierarchies did not tolerate any criticism, he was relegated to the National Office for Development Research. (Ah! Mbongo ll)

In the novellas examined here, Tchibamba describes the precolonial exploration and colonial oppression of the Congo not only to denounce European brutality, but to criticise "neo-colonialism". The times and places where the books were published are significant: N'Gobila was published in Kinshasa in 1972, when the novella's portrait of an august chief would have pleased Mobutists if they did not look too closely at Tchibamba's criticisms of Africans who colluded with imperialists. In 1981, after Tchibamba had retired from his disappointing work at the National Office for Development Research, Ngemena was published in Yaoundé, Cameroon. Tchibamba's damning criticisms of "neo-colonialism", which will be further analysed shortly, did not actually appear in his own country, distancing him from potential repercussions.

\section{N'Gobila: a riposte to Stanley, a dialogue with Conrad}

The novella N'Gobila begins at the time of early imperialist exploration, when Henry Morton Stanley and his followers come into contact with the Mswata people and their chief, N'Gobila. This novella would partially fit the model of postcolonial counter-discourse proposed by Ashcroft, Griffiths and Tiffin: it becomes an instance when "[r]eceived history is tampered with, rewritten, and realigned from the point of view of the victims" (34). However, the primary reason for Tchibamba's use of a counter-narrative is not to "write back" to the Western canon in general. Specifically, Tchibamba targets Stanley's eulogistic account of his mission "for the cause of civilisation" (104) in The Congo and the Founding of its Free State (1885) and the brutal Belgian regime that he helped to establish. Stanley's 1876-1877 exploration of the Congo River, related in his 1878 book Through the Dark Continent, had been instrumental not only for the mapping, but for the military subjugation, of the Congo for King Leopold II. During the time of the Congo Free State, Conrad would respond to Stanley's account of "destructive progress". While Stanley had praised the administrator Lieutenant Janssen for achieving "great progress in the construction of a commodious house" (409), Conrad subjects the idea of colonialist "progress" to intense scrutiny. His short story An Outpost of Progress (1898) creates a damning portrait of the inept and violent Free State administrators Carlier and Kayerts, and its exposure of Belgian imperialist cruelty is arguably even more trenchant than his later criticisms of oppressive behaviour in Heart of Darkness (1899). Yet Conrad's most scathing criticism is reserved for the Sierra Leonean character Makola, who sells both the Station's African employees and some of Gobila's men to slave-traders in exchange for ivory (Outpost 16). Scholars such as Jakob Lothe have remarked on Conrad's “ironic play on "progress"' (49) and detailed his deployment of irony.

Irony is also prominent in Tchibamba's N'Gobila, but he deploys it not only to correct Conrad, but to build on his critique of Belgian practices. This is far more complex than a case of 'writing back'; while Tchibamba exposes the inadequacies of Conrad's account, correcting the spelling of "Gobila's" name to "N'Gobila" and offering a Congolese perspective on the Mswata people, he also aligns his own novella with Conrad's criticisms of the Free State. Tchibamba's use of irony is evident from the outset of his description of the establishment of the station, which highlights the double standards at the early stages of the subjugation of the Congo:

D'habiles contacts qu'il parvint à nouer avec N'Gobila inondé de cadeaux de pacotilles, Bula Matari réussit à obtenir l'autorisation, non pas de "prendre possession du pays", mais simplement de "construire un petit village" sur une butteà à roximité du fleuve pour y séjourner en qualité de simple hôte. 
From the skilful links that he managed to forge with N'Gobila, whom he had showered with gifts of junk, Bula Matari succeeded in obtaining permission, not to "take possession of the country", but simply to "build a little village" on a hillock near the river and stay there as a simple guest. (N'Gobila 47)

Tchibamba uses "Bula Matari", Stanley's soubriquet among the Bakongo. The nickname means "the stonebreaker, because he could break up rocks with dynamite". Yet later the term "would also be used to refer to the colonial regime" (van Reybrouck 46). The moniker "breaker of rocks" also captures Stanley and the Belgians' intransigence. Nicknames such as "You-You-You", a mocking rendition of the Administrator's black followers' Pidgin English, and "Mistantèle Ndundu Djiê" for the Administrator's habit of cursing "Nom de Dieu!" (43), satirise both white settlers and black accomplices in the imperialist project. Tchibamba lays the satire on thickly: repeating "simplement" and "simple" in the passage quoted above stresses that this occupation is anything but simple. His use of quotation marks (guillemets in the original) to mock the duplicity of Bula Matari's assertions further reinforces the text's ironic sting. Quotation marks are used ironically again to report the Administrator's speech: he is described as going "se "promener" (for a walk) to Maluki, when his actual purpose is to forge "de nouvelles alliances" (50): establishing new alliances in the interests of his imperialist mission. Here, irony is used to expose the duplicity of this barely-concealed venture to subjugate new parts of the Congo. A Mswata warrior disguised as N'Gobila is interrogated by the Administrator, and here Tchibamba employs irony by quoting direct speech:

Ne sais-tu pas encore que ce pays appartient au Bula Matari? [...] Tu as besoin d'une bonne correction pour t'apprendre la Civilisation.

Don't you know yet that this country belongs to Bula Matari? [...] You need a good hiding to teach you some Civilisation. (N'Gobila 76)

"Civilisation" is as critical a concept for Tchibamba's narrative, as "progress" had been for Conrad; here, Tchibamba's ironic capitalising of "Civilisation" exposes the duplicity of the European imperialist mission and builds on Conrad's earlier criticisms.

Tchibamba further interrogates the concept of civilisation, and particularly African civilisations before colonisation, in his descriptions of N'Gobila. His characterisation of N'Gobila is without irony; instead, it offers a corrective to Stanley and Conrad's accounts. Stanley shows "Gobila" as "an exceedingly stout man, of about forty-five, very unking-like in dress" (405), a servile collaborator happy to admit Stanley "as his neighbour and friend" (406). The so-called "Papa Gobila", occasionally drunken (407-8), is characterised as an avuncular buffoon, capable of ridiculing white men but supposedly keen to adopt them: "The stout old man regarded [Lieutenant Janssen] with paternal pride. Gobila, with rare humour, had christened his white son 'Susu Mpembe', or the 'White Chicken" (409). "Gobila" is little more dignified in Conrad's version of events. He is "a gray-headed savage, thin and black, with a white cloth round his loins and a mangy panther skin hanging over his back" (Outpost 7-8). Yet Conrad's characterisation of "Gobila" is not invariably unsympathetic: he is described as prudently "cautious" around white men after the slaving raid (17). Conrad encourages his reader to sympathise more with "Gobila" than with Makola, Carlier, or Kayerts, but the chief is still stereotyped according to racist European ideas of the time. Tchibamba's account restores kingly dignity to N'Gobila, and foregrounds his prowess as an explorer and military leader. The Mswata chief is:

Majestueusement assis sous un monumental dais de rameaux de palmiers et entouré de son aréopage d'imposants dignitaires.

Majestically seated beneath an imposing canopy of palm branches and surrounded by his council of impressive dignitaries. (N'Gobila 52)

The crowd is "hanging on [every word from] his august lips" ("accrochée à ses lèvres augustes") (52). Majestic, imposing, impressive, august: Tchibamba's adjectives labour the point here, but he restores the regal reputation of Stanley's drunkard and Conrad's "savage". It was via river-exploration and armed subjugation that Stanley helped to bring Congolese territory under the Belgian king's control, and Tchibamba's account demonstrates that N'Gobila's people are quite capable of such feats themselves. The Mswata "étaient perpétuellement sur le fleuve dans leurs pirogues-huttes, écumant les contrées riveraines" (were always on the river in their canoe-huts, skimming through the waterside regions) (46). Here is a history of precolonial exploration that offers a riposte to European claims of “discovery”, such as Stanley's account of “discovering” Lake Leopold II (Stanley 225). The Mswata have suffered 
defeats at the hands of other tribes, but Tchibamba points out that it is N'Gobila's actions that lead them to victory and conquest:

[a]près avoir réduit par les armes la résistance des premiers occupants et conquis une grande partie des terres au-delà du grand plateau de l'arrière-pays, les Mswata attribuèrent à leur héros le titre du roi.

After having quelled the resistance of the first inhabitants by force of arms and conquered a great swathe of the lands beyond the high plateau of the hinterland, the Mswata bestowed the title of king upon their hero. (N'Gobila 46)

This history of precolonial conquests and military exploits is set against the recent incursions of Europeans on the following page: "des explorateurs européens commencèrent à remonter le Pool" (European explorers began to journey up the Pool) (47). Tchibamba's account champions indigenous traditions and puts the concept of western "civilisation" under pressure: the Mswata have ambitions to expand their territory, a sophisticated system of rule by king and council, and a detailed knowledge of navigation and topography. "Progress" clearly does not come with European invasions. Yet Tchibamba's descriptions of the Mswata's military ambitions also resonates with the post-independence era of internal colonialism. Tchibamba presents N'Gobila as a responsible ruler whose ambitions for territorial expansion are justified and who resists European incursions after initial co-operation. The author sets up an implicit contrast with the complex alliances with foreign powers that rival Congolese politicians established during the Congo's First Republic (1960-65). ${ }^{3}$ For Tchibamba, the early 1970s represented a welcome time for Congolese self-rule and an opportunity to write about an ideal historical ruler- but important ambiguities about contemporary politics arise elsewhere in the novella.

Twenty years later, N'Gobila is able to foresee an end to the repressive era of colonial taxes and licenses (88). He prophesies a day when:

[N] os descendants redeviendront maîtres de ce pays [...] Huit décennies plus tard, la lointaine vision du vieillard allait devenir la réalité.

Our descendants will become masters of this country again [...] Eight decades later, the old man's distant vision would become reality. (N'Gobila 89)

This is a celebration of Congolese independence, but Tchibamba's narrative does resonate with contemporary aspects of Mobutu's regime. N'Gobila's people mount an anti-colonial resistance by transforming into "leopard men". As Gehrmann notes, “'Leopard men' as agents of secret societies, who often carried out murders, were known in different parts of the Congo during the $19^{\text {th }}$ and $20^{\text {th }}$ centuries. Considered a potential menace to colonialism, their 'magical power' fascinated colonial artists and writers [...] Tchibamba makes strategic use of their threatening reputation" (24-5). ${ }^{4}$ Nevertheless, Gehrmann does not mention that the image would have had contemporary resonances: the mention of "leopard men" would have reminded readers in 1972 of Mobutu's leopard skin chieftain's hat (van Reybrouck 341), worn in spite of his lack of royal blood, and his Order of the Leopard (355), set up to honour foreign dignitaries and Congolese officials. The leopard had replaced the lion as a national symbol of power in Mobutu's public ceremonies. The irony here is that Tchibamba's "leopard-men" have considerably more anti-colonial bite than the foreign members of Mobutu's Order of the Leopard, who included Queen Elizabeth II. There is also an important ambiguity in the words that Tchibamba attributes to N'Gobila. The chief's statement that the country will one day become "legitime héritage de leurs aieeux" (the legitimate inheritance of their ancestors) (N'Gobila 89) contains an important double meaning. Although Tchibamba celebrates Congolese independence, and Mobutu's presence was viewed positively in the early 1970s, with hindsight, the kleptocracy that he instituted raises the important question of who exactly benefits from independence. Later in his career, Tchibamba will comment on the ruling classes' subsequent collusion with foreign powers. He ends his narrative with a final, ironic flourish, exposing his narrator as profoundly unreliable:

Ce récit vient de l'arsenal de menteries apothéotiques qui ont longtemps auréolé la terrible épopée de Mfumu N'Gobila [...]. Ici, s'arrête la part du narrateur, éternel menteur.

This tale comes from the collection of deifying lies that have long endowed the terrible epic of Mfumu N'Gobila [...]. Here ends the part of the narrator, that perpetual liar. (N'Gobila 90)

The "lying" narrator is tasked with retelling "the legends of the region" (90). Throughout, Tchibamba's narrative has focused closely on the exploits of a people within its region. This goes subtly against the grain of Mobutu's 
recours à l'authenticité: it was national pride, not affiliation to social and ethnic groups, that Mobutu and his cronies initially wished to promulgate. ${ }^{5}$ Tchibamba's coda to his novella encourages his reader to question the veracity of all aspects of his account, and this creates several important dimensions: it reinforces the reader's interpretation of the tale as an imaginative cultural narrative for the Mswata, not as an historical account; but it also encourages the reader to turn a critical gaze on how poorly Mobutu compared with N'Gobila. Thus, while Tchibamba can be seen to repudiate Stanley and correct Conrad, he uses Conrad's ironic criticisms of "progress" to target not only imperialism, but to hint at his dissatisfaction with the regime that replaced it.

\section{Ngemena: a dialogue with Conrad}

If Tchibamba had engaged with Conrad in N'Gobila, his response to Conrad in Ngemena is more lengthy and complex. Gehrmann's view is that the "textual confrontation" with Conrad sees Tchibamba using Conradian ideas "not as continuation of his central metaphors and symbols, but as contestation" (15). Yet Gehrmann concedes that there are even parallels between Heart of Darkness and other works by Tchibamba: the European journey into the Congolese forest is echoed in the novella La Récompense de la cruauté (19). Her model of counter-discourse does not account for why Tchibamba responds so frequently to Conradian tropes. Gehrmann has used Ngemena as an example of Tchibamba's realistic fiction, in which "an African point of view is focused on in order to elaborate a quasi-documentary portrait of colonial society with its inherent structural violence" (13). It is indisputable that Tchibamba offers a Congolese point of view: an author's note that closes the novel describes the plot and events as "véridiques et vécus réellement" (true and truly experienced) (Ngemena 109), and it is inspired by personal experience. There are also important "picaresque" elements: the lengthy and frustrating encounters with colonial bureaucrats often read as more Kafkaesque than Conradian. Yet Tchibamba uses occasional references to Conrad to target not only European colonials, but neo-colonial power relations after independence-and sycophantic black collaborators in such schemes. Ngemena is in many respects Tchibamba's most detailed and intricate dialogue with a European author, and it displays multiple layers of intertextual response, critique, and ambivalence.

Tchibamba's preface to this novella is highly important for its criticisms of both colonialism and the forms of oppression that replaced it. This is Tchibamba's motive for setting his novella in colonial times:

Malgré les "indépendances" qui, après la spécieuse décolonisation de façade, ont installéla plupart des pays de notre continent sur le pavois de la souveraineté en vertu de laquelle des vieilles colonies sont devenues de jeunes États (après 300, 200, 100, voire 80 ans de domination étrangère), l'obstacle fondamental contre lequel bute encore aujourd' hui notre élan dans tous les domaines de la vie nationale a pour origine le phénomène que nous croyions enterré: le colonialisme. La persistance de ce phénomène dépersonnalisant (déjà mué en un irritant néo-colonialisme où baignent avec euphorie tous nos gouvernements nationaux et nos bourgeois de fraîche date) ne peut que nous inciter à exhumer de temps en temps, sous forme de revues rétrospectives, des anecdotes véridiques, même fragmentaires, se rapportant à certaines anciennes situations marquées par des circonstances particulièrement intolérables, voire tragiques, que nous avons connues.

In spite of the "independences" which after the specious appearance of decolonisation, raised most of the countries of our continent on the pedestals of sovereignty under which old colonies became young states (after 300, 200, 100, even 80 years of foreign domination), the fundamental obstacle against which our momentum in all areas of national life still stumbles today, has as its origin the phenomenon that we believed was buried: colonialism. The persistence of this depersonalising phenomenon (already transformed into an irritating neo-colonialism in which all our national governments and our new bourgeoisie have been wallowing ecstatically) can only incite us to exhume from time to time, in the form of retrospective reviews, true anecdotes, even fragmentary, relating to certain former situations marked by particularly intolerable, or even tragic, circumstances that we experienced. (Ngemena 8)

He stresses that such stories should be remembered, since:

$[L]$ e passé est toujours vivant (et joue même un rôle actif dans les trames politiques où n'arrêtent plus de s'enferrer nos dirigeants nationaux incapables de décoller de l'ornière du passé colonial).

Current affairs are very often a repetition of past tragedies and the past lives on (and even plays an active role in the political plots in which our national leaders continually entangle themselves, incapable of getting out of the rut of the colonial past). (8-9).

Recalling Boehmer's non-essentialising model of colonial and postcolonial discourse, Tchibamba stresses that not all colonials behaved as "négrophobes", nor did they all rule with a rod of iron ("la férule") (23)-but conceding that 
they were not all "négrophobes" is not exactly a resounding endorsement of them. He stresses that not all colonials were brutal, conceding that certain individuals could be "sympathiques et vraiment fraternels" (pleasant and truly fraternal) (23). However, some of his most damning criticisms are reserved for brutal colonial administrators.

The novel illustrates the variety of interactions between Congolese people and Europeans-and an important dimension of this is Tchibamba's exposure of the pervasiveness of colonial brutality, from the physical violence perpetrated by the Belgian captain of the ferry Eendracht (48) and the complicity of his Congolese lackey "Mbénga", right up to abuses of power by high-ranking colonial officials such as former highwayman von Lörrach (56) and Nazi sympathiser von Hermann Schlechting (108). ${ }^{6}$ However, he adds further ammunition to his criticisms by entering into dialogue with Conrad's exposure of atrocities in the Belgian Congo Free State in Heart of Darkness. Tchibamba updates Conrad by creating a journey into the interior along the Congo River, a trek inland through a forest where cannibalism is allegedly practised, and characters that recall Conrad's exhausted railway workers and diseased Free State profiteers. Tchibamba is more concerned with exposing the abuses and inconsistencies of the colonial project than with creating an African rewriting of Heart of Darkness, and other African authors and artists make their responses to Conrad more overt. ${ }^{7}$ Yet Tchibamba points to continuity between the atrocities Conrad witnessed during his 1890 journey upriver, and continued discrimination in 1948.

Since the novel has never been translated into English in its entirety, a brief plot summary is helpful here. The well-educated Congolese clerk Pualo Mopodime must travel from his home in Kinshasa to see his aunt in his natal town in Libéngé, in the province of Oubangui. A voyage up the River Congo, and a subsequent overland journey, see Pualo coming into contact with a whole spectrum of European administrators of different nationalities, African opponents of the regime and collaborators, and Africans from many parts of the Congo and other colonies. Tchibamba reinvents not only the Conradian river-voyage, but Conrad's characters.

Indeed, in the preface to Ngemena, Tchibamba lends weight to his critique of colonial (and neo-colonial) policies by employing a Conradian image. He draws on Kurtz's painting of a woman carrying the torch of civilisation, her blindfold evoking the brutality that a benevolent image of colonialism suppresses (Heart of Darkness 29). Here is Tchibamba's response to this Conradian image:

Nous humilier à tout instant, nous brutaliser en toute occasion, là était pour eux la règle de conduite indispensable à l'assiette et à la sécurité de la sacro-sainte personnalité du colonial porteur du flambeau de la civilisation.

Humiliating us every minute, abusing us at every opportunity, there was the code of conduct indispensible to the establishment and security of the sacrosanct person of the colonial, bearer of the torch of civilisation. (Ngemena 7)

Here, Tchibamba's characteristic irony takes the place of Conrad's use of the blindfold to draw out colonial double standards. Tchibamba uses the river-journey to dramatise tensions between different social classes, and between Congolese people who collaborate with or resist their oppressors. The riverboat Eendracht, on which Pualo travels, becomes a microcosm of colonial society and brings these tensions to a head. Tchibamba examines the issue of how to treat évolués - the educated Congolese middle class - and relations between Congolese people and their European masters. The 1940s had witnessed the rise of the évolués (a problematic colonial label meaning 'developed' or 'evolved'). Their status entitled them to a 'social merit card' and certain limited privileges that colonials normally enjoyed (Ringrose 24-5). Tchibamba mocks this system, which ended up distancing the évolués from both Europeans (Ringrose 25) and from other Congolese people. Pualo's ticket entitles him to a "third-class bridge cabin for évolués" (Ngemena 35). For wanting a third-class cabin, the ferry conductor nicknamed Mbénga ridicules Pualo for being one of "les 'Blancs-Noirs' de Kinshasa imbus de prétentions idiotes" (the Kinshasa 'white-blacks' full of idiotic ambitions) (38). Mopodime's education, class, and supposed adoption of European mannerisms add an intricate layer of tension to the already fraught relationship between urbane Kinshasa clerk and hinterland ferryman. However, with the irony that characterised Ngando, Tchibamba describes Mbénga as having "the authority of a white man". Tchibamba exposes Mbénga himself as one of the "Blancs-Noirs" when he separates a black Congolese man from his mixed-race wife, sending her up to the second class cabins "avec les Blancs ses pères" ("with her relatives the Whites") (38).

Conrad, too, had put into play the fractured relationship between black people who collaborated with the Free State and their white employers aboard the Roi des Belges. Amid concerns that indigenous Congolese people will attack the steamer, a black headman from a British colony announces that he will "catch 'im" and "Eat 'im" (Heart of Darkness 49). Conrad makes it clear that the differences between African ethnic groups are marked, and 
sometimes lead to open hostility. Yet the "partnership", "bond", and "distant kinship" (62) that develop between Marlow and his inept helmsman, illustrate the intricate sympathies that are created between Europeans and some African characters, and the collusion of certain Africans with European colonialists. Conrad does not present European colonialism as a monolithic entity, nor Africans as a homogeneous group united against their oppressors.

When he updates Conrad's iconic river-voyage for a 1948 ferryboat journey up the River Congo, Tchibamba creates a renewed sense of the complicities and tensions among Congolese people under the Belgian colonial regime. Yet he goes beyond Conrad's narrative by showing how the issue of class plays a part in Mbénga's assertion of his power over Mopodime. Tchibamba takes aim at divisive colonial practices, such as reinforcing class segregation by providing évolués with negligible 'privileges'. Yet by the time Tchibamba published this novella, he had worked in several minor posts under the Mobutu administration, was receiving less literary recognition in his home town of Kinshasa than abroad, and was "déçu par le comportement humain" ("disappointed by human behaviour") (Ah! Mbongo 12). Given his dissatisfaction at this time, his critique of the way Mbénga colludes with Europeans is also applicable to the "néo-colonialisme" (Ngemena 8) that he attacks in the preface.

Tchibamba continues his dialogue with Conrad during the course of the river-journey, and his descriptions both echo, and revise, Heart of Darkness's evocations of the journey upstream:

De part et d'autre, la paix du règne végétal, la tranquillité et le silence imprègnent les deux rives d'un climat nostalgique, lequel flotte sur létendue liquide qui file sans arrêt, envoûtant et mystérieux. Tandis que sur la terre ferme, rares se montrent les habitations des hommes.

On either side, the peace of the plant kingdom, tranquillity, and silence imbu[ed] both banks with a nostalgic atmosphere, which floated on the liquid expanse that ran by without stopping, spellbinding and mysterious. However, human dwellings on firm ground were rarely seen. (Ngemena 49-50)

Tchibamba is responding to Conrad's description of forest and river as primordial realms immersed in silence: Going up that river was like travelling back to the earliest beginnings of the world, when vegetation rioted on the earth and the big trees were kings. An empty stream, a great silence, an impenetrable forest. [...] There were moments when one's past came back to one, as it will sometimes when you have not a moment to spare to yourself; but it came in the shape of an unrestful and noisy dream, remembered with wonder amongst the overwhelming realities of this strange world of plants, and water, and silence. And this stillness of life did not in the least resemble a peace. (Heart of Darkness 4l)

Tchibamba's "plant kingdom" responds to Conrad's "world of plants"; his "nostalgic atmosphere" echoes Conrad's moments when the past comes back to Marlow. Yet the critical difference between these passages is that while Conrad's river is a restless place of primordial menace, Tchibamba's vocabulary of "peace" and "tranquillity" offers the opposite interpretation. Tchibamba's Congolese perspective complicates a European picture of the Congo River and its forests as sites of threatening alterity.

Tchibamba's echoes of, and revisions of, Conrad's voyage into the interior continue even when Pualo disembarks from the ferry. The reputation of forest peoples whose territory Pualo passes through, sets up a significant dialogue with Conrad and with European stereotypes about Africa. In his famous attack on Conrad, Achebe singled out two examples of the threat of cannibalism in Heart of Darkness (qtd in Heart of Darkness xlvii-xlviii). It is notable that Marlow does not actually witness any cannibal practices, and that the European drive for capitalist consumption is also described in terms that evoke cannibalism: Kurtz opens his mouth "as though he had wanted to swallow all the air, all the earth, all the men before him" (74). Tchibamba revises this by stating that there are indeed people in the Upper Congo who had been cannibals, although this behaviour had been largely abandoned and the martial force of their tribe had been crushed. Historically, the Ngabaka Minangéndé warriors did not return home from a raid:

[2] ue munis d'un paquet de feuilles contenant de la chair humaine destinée aux banquets [...] cette pratique n'était pas encore totalement abandonée, bien que ne s'accomplissant plus avec des démonstrations bruyantes.

Unless they were supplied with a bundle of leaves containing human flesh destined for [their] banquets [...] this practice had not yet been completely abandoned, even though it was no longer accompanied by noisy displays. (Ngemena 76)

However, no longer warlike or bloodthirsty, the Minangéndé who had become "civilised" (Tchibamba's cautionary quotation marks) now suffered intolerable punishments; such ignominy would have been countered with a bloodbath ("bain de sang") in former years, but they are now only able to offer resistance in the form of "des protesta- 
tions timides vite 'oubliées' sans réparations" (shy protestations, quickly 'forgotten', without compensation) (76). The Congolese people whom Marlow encounters offer armed resistance to the steamer and its white and black crew; Tchibamba's revision of Conrad's account neither condemns nor praises the former cannibals, but rather evokes the pathos of a people whose capacity to resist has been utterly destroyed. Congolese people certainly organised strikes and mutinies to demand better treatment in the Belgian Congo in the 1940s (Yervasi 16-7). Amid such a climate, Tchibamba reveals the Minangéndé's powerlessness as pitiable.

If Conrad's Kurtz embodies the Congo Free State's consumptive appetite for ivory, Tchibamba's narrative focuses on two natural consumer products cultivated in the colonial Belgian Congo: rubber and cotton. In the novella, the company Cotonco has established plantations of these cash crops, and a factory for their preliminary processing (Ngemena 78). The colonial Compagnie Cotonnière Congolaise (Cotonco) actually existed; this adds to the novella's verisimilitude and focuses Tchimbamba's critique of colonial labour practices on an historical target. The village of Gemena is surrounded by plantations (78) where political "relégués" (exiles) are put to work (80). Yervasi notes that "After several uprisings throughout the 1930s, the Belgian authorities constructed exile or relégation camps to contain insurgents" (16). The aging political exile whom Mopodime meets has been banished specifically for being part of the "Ngunza" religion (Ngemena 82), a radical anti-colonial movement (Mélice 34). The name of the place, "Gemena", is a colonial mispronunciation of the Ngbaka word Ngemena, which means "rejeté, chassé, banni, déportê" (rejected, hunted, exiled, deported) and was used of an individual who had become a "political outcast" (Ngemena 84). For Tchibamba, the word brings with it painful memories of slavery (84). The ngemena political dissidents:

[F]urent recrutés illico, sous forme de travaux forcés, pour commencer la plantation de coton et d'arbres à caoutchouc.

Were recruited straightaway, in the form of forced labour, to begin the planting of cotton and rubber trees. (90)

And in order to evoke the horror of this new form of slavery in the plantations, Tchibamba draws on Conrad's descriptions of labourers forced to build a railway during the time of the Congo Free State. Here is Conrad's description of the railway workers:

Black rags were wound round their loins, and the short ends behind waggled to and fro like tails. I could see every rib, the joints of their limbs were like knots in a rope; each had an iron collar on his neck and all were connected together with a chain [...] They were called criminals, and the outraged law, like the bursting shells, had come to them. (Heart of Darkness 18)

Here is the passage in which Tchibamba recalls Conrad's description:

[D]es colonnes d'individus enchaînés, hâves, décharnés, déguenillés, poussés comme du bétail, brutalisés jusqu'au sang par les soldats sur la conduite et l'exhortation cruelle de leurs impitoyables chefs blancs armés de revolver [sic]; ceux de ces malheureux qui, n'en pouvant plus, tombaient exténués, étaient abattus et leurs dépouilles abandonnées sur place, offertes aux bêtes carnivores. Et dire que c'était au nom et pour le compte de la civilisation chrétienne que se pratiquaient de telles atrocités [...]

Columns of chained individuals, haggard, scrawny, ragged, goaded like beasts, beaten until they bled by the soldiers under the direction and cruel encouragement of their pitiless white chiefs armed with a revolver [sic]; those unfortunates who, unable to stand it anymore, fell down exhausted, would be killed, and their bodies were abandoned there, given to the carnivorous animals. And to think that it was in the name of and on behalf of Christian civilisation that such atrocities were perpetrated [...] (Ngemena 85)

Tchibamba goes further than Conrad does in his criticisms of the colonial project by explicitly pointing out the hypocrisy of this treatment of forced labourers: "Ô Boula Matari toi qui hier te prétendais anti-esclavagiste [...]" (Oh, Boula Matari, you who claimed yesterday that you were against slavery [...]) (87). The Berlin Act of 1885 had aimed to end slavery in Western and Central Africa, and bound signatories to punish those who continued the trade; this makes the injustice of forced labour systems all the more ironic. Tchibamba's description of the isolated old man Kashidi Mwan'Inzal sets up further intertextual echoes of Conrad:

Marchant au hasard [...] ils eurent néanmoins la chance de découvrir un malheureux vieillard de ngemena tout perclus. Accroupi au pied d'un palmier desséché, à côté d'un semblant de hutte basse à peine couverte de chaume, cet homme était ceint d'une incroyable charpie de rabane tout effilochée; détruit par une précoce décrépitude fertilisée par d’interminables privations débilitantes et des maladies consécutives jamais soignées, ce déshérité n'avait que la poliomyélite comme compagne. 
Wandering aimlessly [...] they nevertheless were lucky enough to discover an unfortunate old paralysed ngemena man. Crouching at the base of a shrivelled palm, by what passed for a low hut barely covered with thatch, this man was wrapped in incredible shreds of frayed raffia; destroyed by an early decrepitude worsened by endless, debilitating deprivations and consecutive, untreated illnesses, this deprived individual had polio as his only companion. (81)

This isolated old man in a forest hut acts as a contrast to Conrad's Kurtz, and Tchibamba echoes some of Conrad's famous descriptions to highlight the ideological differences between the two characters. Both are wracked by disease and close to death, and the encounters with them function as the culminating point of the heroes' journeys into the interior. The two characters even share some physical traits. Mwan'Inzal's head "brillait au sommet de la calvitie, et couverte d'une tempe à l'autre d'une bande de cheveux très blancs" (shone with baldness at the crown, and covered from one temple to the other with a strip of very white hair) (83). This tonsure-like appearance suggests religious devotion, whereas Kurtz's is "impressively bald", resembling "ivory" (Heart of Darkness 59), the commodity he covets. Tchibamba sets the two characters up as contrasting epitomes of colonial megalomania and victimhood. Yet Mwan'Inzal's appearance more closely echoes Conrad's descriptions of exhausted "criminals" (forced labourers) condemned to work on the railway:

They were dying slowly - it was very clear. They were not enemies, they were not criminals, they were nothing earthly now, - nothing but black shadows of disease and starvation. [...] While I stood horror-struck, one of these creatures rose to his hands and knees, and went off on all-fours towards the river to drink. (Heart of Darkness 20)

Conrad's description moves from a group of labourers to a specific individual, to whom Marlow gives a ship's biscuit (20). This is paralleled in Tchibamba's description of the state of relégation, the specific fate of Mwan'Inzal, and Pualo's gesture of filling the old man's jerry can with water when he sees him crawling towards a spring to drink (Ngemena 96). Yet Tchibamba goes beyond Conrad by giving Mwan'Inzal the agency to tell his own story: an important privileging of the Congolese perspective. A primary purpose of setting up these parallels with Conrad is to highlight the way "rebels" and "criminals" were treated during the time of the Free State, and during colonial rule. Kurtz impales the heads of "rebels" (Heart of Darkness 73) on poles outside his hut, and Marlow comments ironically that "Those rebellious heads looked very subdued to me" (73). Although Tchibamba does not document practices that are as horrific as this, condemning Mwan'Inzal and other ngemena exiles to "une mort lente" (a slow death) (Ngemena 86) sets up troubling echoes of Conrad's documentation of the Free State's intransigence.

No character in Ngemena is as cruel as Kurtz, but the chief administrator von Hermann Schlechting, a German who has become a Belgian citizen, shares some traits with him. Kurtz has a German name (Heart of Darkness 74), although he is also part English and part French (61). More significant than the shared origin of their names is the disturbing parallel that Tchibamba creates between von Hermann Schlechting's sympathy with the Nazi genocide and Kurtz's wish to exterminate Congolese people. Tchibamba describes him thus:

[V]on Hermann Schlechting [...] savourait avec délice les récits des atrocités épouvantables inaugurées par ses frères tortionnaires nazis aux camps des mis à mort à sa terre natale à Orianenburg, à Dachau, à Buchenwald [...] Au nom de la civilisation chrétienne il fallait que nos colonisateurs introduisissent de telles pratiques dans cette providentielle 'Dixième Province belge' d'outre-mer qui vola sans hésiter au secours de la 'mère-patrie' terrassée, meurtrie, gémissante sous les bottes hitlériennes.

[V]on Hermann Schlechting [...] relished with delight tales of the fearful atrocities introduced by his Nazi torturer brothers at the camps of people put to death in his homeland at Orianenburg, at Dachau, at Buchenwald [...] In the name of Christian civilisation it was necessary for our colonisers to introduce such practices into the providential 'Tenth Belgian Province' overseas, which rushed unhesitatingly to the aid of the fallen, bruised 'mother country', groaning under Hitlerian jackboots. (Ngemena 108)

Tchibamba's caustic likening of Belgian colonial policy to the Nazi genocide lambasts colonial policy. Von Hermann Schlechting's admiration of Nazi extermination camps creates a distant echo of the words of Kurtz's pamphlet, which reads, "Exterminate all the brutes!" (Heart of Darkness 62). The death toll during the Congo Free State was "of Holocaust proportions" (Hochschild loc. 94), but did not amount to genocide, as the deaths of Congolese people came about due to appalling labour practices rather than the deliberate targeting of an ethnic group (Hochschild loc. 3877). Yet Tchibamba's evocation of Kurtz-like attitudes that persisted among colonials exposes the continuity between King Leopold's personal commercial fiefdom and the colonial regime. There are 
also disturbing parallels with events that occurred after Congolese independence, such as the ethnic cleansing of the Baluba in 1960 (van Reybrouck 303).

\section{Conclusion}

Tchibamba's dialogue with the two main European precursor books analysed here, An Outpost of Progress and Heart of Darkness, is richly multivalent, comprising elements of affiliation, cultural correction, and parody. While Tchibamba demolishes Stanley's myth of the benevolence of his civilising mission, and corrects Conrad's portrait of an undignified "Gobila", he does so by using a bitingly ironic tone that builds on Conrad's narrative method. Ideologically, his denunciation of colonialism develops and updates Conrad's exposure of the Free State's ironies and brutality. While Ngobila indisputably celebrates Congolese self-government, Tchibamba subtly champions tribal allegiances and a leader more regal than Mobutu. Foreshadowing his later critique of neo-colonialism, he subjects African collaborators in the imperialist project to stingingly ironic criticism. Distinctive irony is the hallmark of Tchibamba's descriptions of colonial "progress" from Ngando right up to his evocations of mass slaughter in the name of "Christian civilisation" in Ngemena (108). Heart of Darkness is the most important European intertext in Ngemena, informing the description of the voyage into the interior and contributing to Tchibamba's focus on socalled "criminals" and "political exiles". Published in an era when colonialism had been replaced by other forms of oppression, many of Tchibamba's narratives set in precolonial and colonial times are applicable to the problems of "néo-colonialisme" (Ngemena 8). Tchibamba responds to European precursors to chronicle precolonial and colonial oppression, but also to raise provocative questions about new forms of imperialist behaviour.

\section{Acknowledgements}

I am grateful to the University of Central Lancashire's Institute for Black Atlantic Research for their support with writing this article. Many thanks to Kasongo Kapanga for his advice and to Rachel Gnagniko for her help with translations and Central African French.

\section{Notes}

1. Some sections of Tchibamba's first novella Ngando have been translated by Kapanga and are included in his 2009 article and 2017 monograph. All translations of titles and excerpts from Tchibamba's work in this article are mine.

2. Kapanga notes that the hanging did not relate to the authenticity debate, and that people were less shocked by it than one might expect: Mobutu's act of public execution was seen as a deterrent to potential dissenters (Kapanga and Reddick).

3. The period of the Congo's 'First Republic' from 1960 to 1965 was turbulent, bloody, and complex and saw rival leaders forming alliances with the West and the Soviet Union. Van Reybrouck notes that "Kasavubu and Mobutu were being courted by the CIA, Tshombe at moments was the plaything of his Belgian advisers, and Lumumba was under enormous pressure from the United States, the Soviet Union, and the United Nations. The power struggle among the four politicians was greatly amplified and complicated by the ideological tug of war taking place within the international community" (282).

4. For an anti-colonial movement of 'leopard people' that killed both locals and Europeans, see van Reybrouck (154).

5. Initially, the "authenticite" policy was intended to be unitary: hence the slogan "yes to tribes, no to tribalism". Kapanga notes that his policy of moving civil servants all over the country is recognised to this day as one of the unifying factors that has helped in the creation of a national identity (Kapanga and Reddick). For further information about how Mobutu later manipulated ethnic rivalries to shore up his failing regime, see Wright (90).

6. This name means "tigerfish" in Lingala (Ngemena 37), and suggests the predatory behaviour of the fish in Malébo Lake that Tchibamba had described at the beginning of Légende.

7. For more overt African responses to Conrad that specifically highlights its dialogue with him, see Zakes Mda's novel Heart of Redness or Nyaba Leon Ouedraogo's photo-essay The Phantoms of Congo River.

8. The French for a 'death camp' is camp de la mort. Tchibamba's wording, le camp des mis à mort, "camps of those put to death", focuses the reader's attention on the victims rather than the dehumanising fact of their death.

Works Cited

Achebe, Chinua. "An Image of Africa." Heart of Darkness and Selections from the Congo Diary. Joseph Conrad. Random House, 1999. pp. xlv-lii.

Adelman, Kenneth Lee. "The Recourse to Authenticity and Négritude in Zaïre." The Journal of Modern African Studies vol. 13, no. 1, 1975, pp. 134-9. DOI: https://doi.org/10.1017/s0022278x00025465.

Ashcroft, Bill, Gareth Griffiths \& Helen Tiffin. The Empire Writes Back: Theory and Practice in Post-Colonial Literatures. Routledge, 1989.

Badru, Pade. "Ethnic conflict and state formation in post-colonial Africa: A comparative study of ethnic genocide in the Congo, Liberia, Nigeria, and Rwanda-Burundi." Journal of Third World Studies vol. 27, no. 2, 2010, pp. 149-69.

Boehmer, Elleke. Colonial and Postcolonial Literature: Migrant Metaphors. Oxford U P, 1995.

Caminero-Santangelo, Byron. African Fiction and Joseph Conrad: Postcolonial Intertextuality. SUNY U P, 2004.

Conrad, Joseph. Heart of Darkness and Selections from the Congo Diary. Random House, 1999. An Outpost of Progress. Krill, 2015. 
Duerden, Dennis \& Cosmo Pieterse, eds. African Writers Talking: A Collection of Radio Interviews. Africana, 1974

Fasselt, Rebecca. "(Post)Colonial We-Narratives \& the 'Writing Back' Paradigm: Joseph Conrad's The Nigger of the 'Narcissus' \& Ngũgĩ wa Thiong'o's A Grain of Wheat." Poetics Today vol. 37, no. 1, 2016, pp. 155-79. DOI: https://doi. org/10.1215/03335372-3452655.

Fraiture, Pierre-Philippe. "Belgium and its Colonies: Introduction." A Historical Companion to Postcolonial Literatures: Continental Europe and Its Empires. Eds. Prem Poddar, Rajeev S. Patke \& Lars Jenssen. Edinburgh U P, pp. 7-11.

Gehrmann, Susanne. "Remembering colonial violence: Inter/textual strategies of Congolese authors." Tydskrifvir Letterkunde vol. 46, no. 1, 2009, pp. 11-27. DOI: https://doi.org/10.4314/tvl.v46il.29838.

Halen, Pierre. "Narratives of Empire: (Post)colonial Congo." A Historical Companion to Postcolonial Literatures: Continental Europe and Its Empires. Eds. Prem Poddar, Rajeev S. Patke \& Lars Jenssen. Edinburgh U P, pp. 42-7.

Hochschild, Adam. King Leopold's Ghost: A Study of Greed, Terror and Heroism in Colonial Africa. Pan, 1998. Kindle.

Kadima-Nzuji, Mukala. La littérature zaïroise de langue française (1945-1965). Kartala, 1984. DOI: https://doi.org/10.3917/kart. kadim.2000.01.

Kapanga, Kasongo. "Legitimizing the invented Congolese space: The gaze from within in early Congolese fiction." Tydskrif vir Letterkunde vol. 46, no. 1, 2009, 28-42. DOI: https://doi.org/10.4314/tvl.v46il.29839.

. The Writing of the Nation: Expressing Identity through Congolese Literary Texts and Films. Africa World P, 2017.

Kapanga, Kasongo \& Yvonne Reddick. Email correspondence. 18 Nov. 2016.

Lagae, Johan \& Kim De Raedt. "Building for 'l'Authenticité': Eugène Palumbo and the Architecture of Mobutu's Congo." Journal of Architectural Education vol. 68, no. 2, 2014, pp. 178-89. DOI: https://doi.org/10.1080/10464883.2014.937235.

Loomba, Ania. Colonialism/Postcolonialism, $3^{\text {rd }}$ ed. Routledge, 2015

Lothe, Jakob. Conrad's Narrative Method. Oxford U P, 1984.

Mélice, Anne. "Simon Kimbangu." A Historical Companion to Postcolonial Literatures: Continental Europe and its Empires. Eds. Prem Poddar, Rajeev S. Patke \& Lars Jenssen. Edinburgh U P, 2008, pp. 33-5.

Naipaul, V. S. "Conrad's Darkness." New York Review of Books. 17 Oct. 1974.

Ringrose, Priscilla. "Evolués." Historical Companion to Postcolonial Literatures: Continental Europe and its Empires. Eds. Prem Poddar, Rajeev Patke \& Lars Jensen. Edinbugh U P, 2008, pp. 24-6.

Riva, Silvia. Nouvelle histoire de la littérature du Congo-Kinshasa. Trans. Collin Fort. L'Harmattan, 2006.

Stanley, Henry Morton. The Congo and the Founding of Its Free State: A Story of Work and Exploration, vol. II. Cambridge U P 2011.

Tchibamba, Paul Lomami. Ah! Mbongo. Preface by Eliane Tchibamba. L'Harmattan, 2007. La Récompense de la cruauté suivi de N'Gobila des Mswata. Mont Noir, 1972.

Ngando et autres récits. Preface by Mukala Kadima-Nzuji. Présence Africaine, 1982. Ngemena. Editions Clé, 1981.

Tchibamba, Paul Lomami \& Emongo Lomomba. "Le Blanc-Belge au Congo: entretien avec Lomami-Tshibamba par Emongo L.” Zaïre 1885-1985: cent ans de regardes belges. Eds. Jean-Pierre Jacquemin \& Emongo Lomomba. Coopération par l'Éducation et la Culture asbl (CEC), 1985.

Van Reybrouck, David. Congo: The Epic History of a People. Trans. Sam Garrett. Fourth Estate, 2014.

Wright, Alexander. "Ethnic identity in the Democratic Republic of Congo." The State of Africa: Post-Conflict Reconstruction and Development. Eds. Dirk Kotzé \& Hussein Solomon. Africa Institute of South Africa, 2008, pp. 81-105. 